\title{
Enhanced Pretreatment of Winery Solid Waste for High Reducing Sugar Yield
}

\author{
Vincent I. Okudoh, Benjamin I. Okeleye, Isis M. Da-Barca and Seteno K.O. Ntwampe
}

\begin{abstract}
An increasing quantity of Winery solid waste (WSW) generated annually is of environmental concern. This study was aimed to evaluate the pretreatment efficacy of winery waste for biogas production. Samples comprising mainly of grape pomace were collected from a winery in Stellenbosch, South Africa and subsequently pretreated using chemical (Alkaline hydrogen peroxide, AHP) and biological (cellulases and ligninases) methods. To assess their activity, ligninases and cellulases were further used to hydrolyze the pretreated samples both singly and in combination (cocktail). The results showed an increase in reducible sugar $(23 \%)$ with the combined enzymes $(2.06 \mathrm{mg} / \mathrm{mL})$ compared to the individual enzymes $(1.68 \mathrm{mg} / \mathrm{mL})$. The AHP-pretreated biomass also gave higher $(1.900 \mathrm{mg} / \mathrm{mL})$ yields than non-AHP pretreated $(0.102 \mathrm{mg} / \mathrm{mL})$, indicating a significant effect on delignification and de-crystallinization of cellulose in the biomass. This optimization process had significant impact on the valorization of winery solid waste.
\end{abstract}

Keywords - Biogas, ligninase, lignocellulose, pretreatment, winery waste

\section{INTRODUCTION}

About $20 \%$ of grapes (Vitis vinifera) are used in wine production globally, generating berries pomace containing several types of phenolic compounds, as well as lignocellulose [1]. Approximately $1.3-1.5 \mathrm{~kg}$ of pomace (8\% seeds, $10 \%$ stems, $25 \%$ skins and $57 \%$ pulp) is generated per liter of wine in every batch produced. The large quantities of winery solid waste generated annually poses disposal challenges as it contributes to pollution, affecting water bodies, soils, plants and animal's lives if not properly managed [2]. The conversion of winery solid waste to a feedstock for biogas production can be a viable option not only as an alternative waste disposal technique [3], but also as a clean energy source for the wine industry.

Winery solid waste (WSW) contains mainly lignocellulose material which is composed of long-chain polysaccharides such as hemicellulose and cellulose that can be biodegraded by numerous microorganisms, but it can also be composed of more resistant structures such as lignin [4]-[6]. The lignin is mainly from grape marcs and stalks that lower the yield of biogas when used in anaerobic digestion (AD) plants [7]. Lignocellulosic materials have been identified as a major source of fermentable sugars for the production of biofuels and other valuable biomaterials [8]. The structure of lignocellulose is purposely

All Authors are with Bioresource Engineering Research Group (BioERG), Department of Biotechnology, Faculty of Applied Sciences, Cape Peninsula University of Technology, Keizersgracht and Tennant Street, Zonnebloem, P.O. Box 652, Cape Town, 8000, South Africa designed to make the cell wall of plants resistant to disintegration as shown in Fig. 1 [9].

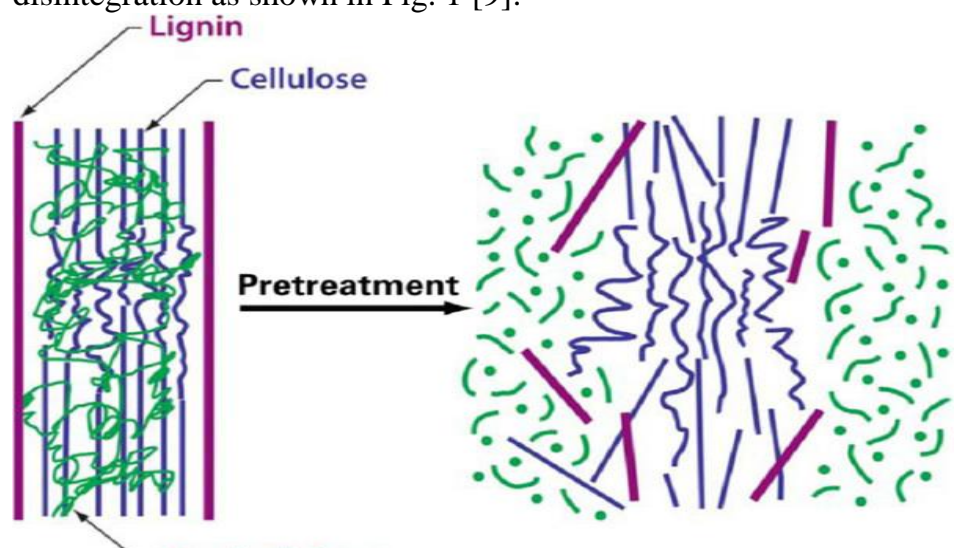

$\checkmark$ Hemicellulose

Fig.1. Primary structure and pretreatment of lignocellulose

Subsequent to milling or grinding, lignocellulose biomass usually undergoes pretreatment in various ways to render the cellulose more available to be degraded into simple fermentable sugars; however a specific mechanism of action has not been delineated [10], [11].

Many types of pretreatment have been identified and each is chosen based on the nature of study or project [11]. Pretreatment strategies that have been used include mechanical (thermal, ultrasonic etc.), chemical (alkali, acid and ozone) and biological (enzymes) or a combination of these treatments [12], [13]. The most employed pretreatments are thermal and ultrasonic, chemical and mechanical for wastewater treatment plant sludge, lignocellulose substrates and Organic Fraction of Municipal Solid Waste (OFMSW) respectively [14]. However, the economic feasibility of these methods remains a challenge and there is a need for further research [12]. The removal of the lignin layer and cellulose de-crystallization becomes necessary for accessibility of enzymes facilitating cellulolysis [15]; hence, a choice of chemical pretreatment such as alkaline hydrogen peroxide (AHP), which is relatively inexpensive and convenient in combination with enzyme hydrolysis for the pretreatment of winery waste.

Alkaline hydrogen peroxide (AHP) is a method for delignification of biomass, typically run at $\mathrm{pH} 11.5$ that involves the formation of highly reactive hydroxyl radicals which targets lignin [16], and partially reduces hemicellulose [17]. The $\mathrm{pH}$ increases during the reaction, therefore, it is unnecessary to adjust it periodically as the hemicellulose and lignin become more soluble. Meanwhile hydrogen chloride must be added to bring the $\mathrm{pH}$ to neutral prior to enzyme hydrolysis [16], [17]. 
Enzyme hydrolysis is advantageous for it requires low energy and mild operational conditions, albeit, it can take extensive periods of time to achieve desired outcomes [11], and would include the high cost of enzymes to be used; however research is being done towards cost-effectiveness by improving enzyme efficiency on cellulolysis [18]. For enzyme hydrolysis, it is important to consider the components of the material to be hydrolyzed, the ratio of biomass to enzyme, type of pretreatment required and the activity of the enzyme used [15].

Fermentation technology is commonly used in the production of industrial enzymes and it may be done in one of two main methods: submerged fermentation $(\mathrm{SmF})$ or solid-state fermentation (SSF). The former is performed by microorganisms in a liquid nutrient broth and the latter on a solid substrate. After fermentation, the enzymes are isolated through various recovery processes, particularly when they are extracellularly produced [19]. The aim of this study was to enrich the pretreatment of WSW for the production of biogas by exploring chemical and biological methods of pretreatment. The highlights include the importance of screening cellulose-degrading bacteria from Zebra (Equus quagga burchelli) manure and the use of white-rot-fungi, $P$. chrysosporium, for production of ligninase enzymes through submerged fermentation and of performing reducing sugars assays to evaluate treatment efficacy.

\section{MATERIALS AND METHODS}

\section{A. Sample Collection and Preparation}

Fresh zebra (Equus quagga burchelli) droppings (ZD) were collected from Stellenbosch farm game reserve and winery solid waste (WSW) collected from Agricultural Research Council, Stellenbosch. The ZD was used as source for cellulose and lignin degrading bacteria. The samples were collected in sterile plastic bags and stored in a refrigerator $\left(4^{\circ} \mathrm{C}\right)$ prior to use. The WSW was analyzed for its compositions or constituents, while $\mathrm{ZD}$ was soaked in warm water, sieved and incubated at $37^{\circ} \mathrm{C}(24$ h) prior to use [6], [20], [21].

\section{B. Isolation of Cellulose Degrading Bacteria (CDB)}

Isolation of Cellulose Degrading Bacteria (CDB) was carried out according to the method of Sethi et al. [22] with modifications. A $1 \%(\mathrm{~m} / \mathrm{v})$ manure solution was prepared by diluting $1 \mathrm{~g}$ of $\mathrm{ZD}$ into $100 \mathrm{~mL}$ of sterile water. A dilution series $\left(10^{-6}\right)$ was carried with $1 \mathrm{~mL}$ from each tube being plated on Carboxymethylcellulose (CMC) agar (supplemented with $1 \mathrm{M} \mathrm{NaCl}$ solution: $29.22 \mathrm{~g} \mathrm{NaCl}$ in $500 \mathrm{~mL}$ of water) in triplicate subsequent to incubation $\left(37^{\circ} \mathrm{C}\right)$ for a few days, with growth being monitored daily. The experiment was conducted in duplicate and culture plates that showed most growth (mostly $10^{-3}$ ) were flooded with iodine for 15 minutes and washed $(\mathrm{n}=3)$ with $1 \mathrm{M} \mathrm{NaCl}$ solution. Colonies with a clear zone around it were selected and sub-cultured on CMC agar plates and incubated $\left(37^{\circ} \mathrm{C}\right)$ for $24 \mathrm{~h}$.

\section{Production of Cellulases}

Cellulase production was done by means of $\mathrm{SmF}$. Approximately $0.5 \mathrm{McFarland}$ standard of $\mathrm{CDB}$ was grown on an enrichment medium (EM) containing $(\mathrm{m} / \mathrm{v}) ; 0.03 \% \mathrm{MgSO}_{4}$,
$0.2 \% \mathrm{~K}_{2} \mathrm{HPO}_{4}, 1 \%$ glucose, and $0.25 \% \mathrm{NH}_{4} \mathrm{SO}_{4}$ prepared in $1 \%$ $(\mathrm{m} / \mathrm{v})$ peptone water and incubated $\left(37^{\circ} \mathrm{C}\right)$ overnight. Cellulase was produced by inoculating $1 \mathrm{~mL}$ of CBD onto $99 \mathrm{~mL}$ of EM supplemented with $1 \%(\mathrm{~m} / \mathrm{v}) \mathrm{WSW}$ in place of glucose and incubated at $37^{\circ} \mathrm{C}$ and $140 \mathrm{rpm}$ for $24 \mathrm{~h}$. Cellulase production was carried out in duplicate; a set was incubated in a shaker incubator and the other in a stationary incubator in order to assess the effect of mechanical agitation on enzyme production. After incubation, the broth was centrifuged at $14,000 \mathrm{x} g$ for 10 $\min$ at $4^{\circ} \mathrm{C}$ to collect the enzyme solution [23].

\section{Cellulase activity assay}

Assay for cellulase activity (CA) was done according to Rathore [21] procedure with some modifications. CA was measured against the glucose standard curve at $575 \mathrm{~nm}$ wavelength based on enzyme dilution ratio (EDR) required to release $0.5 \mathrm{mg}$ glucose $(\mathrm{G})$ by plotting a graph of glucose liberated against enzyme concentration. CA was calculated using Eq. (1) (unit per liter; U/L):

$$
C A=\frac{G}{E D R}
$$

\section{E. Production of Ligninases}

Phanerochaete chrysosporium BKMF 1767 (ATCC 24725) culture was used for Ligninase production according to the methods described by Ntwampe et al. [20]. Lignin peroxidase activity ( $1 \mu \mathrm{mol}$ veratryl alcohol oxidized to veratraldehyde per minute) was measured. Activity (U/L) was calculated every $10 \mathrm{~s}$ using Eq. (s) (2) and (3):

$$
\text { Activity }\left(\frac{U}{L}\right)=\left[\frac{d A}{d t} X \frac{\text { Dilution factor }}{\varepsilon}\right] 60 \times 10^{6}
$$

$$
\text { Dilution factor }=\frac{\text { Total volume of solution }}{\text { Total volume of sample }}
$$

\section{F. Alkaline Hydrogen Peroxide Pretreatment}

WSW for biogas production was pretreated according to Cabrera et al. [24], with minor changes. A volume $(50 \mathrm{~mL})$ of $\mathrm{H}_{2} \mathrm{O}_{2}(7.5 \%)$ adjusted to $\mathrm{pH}$ of 11.5 using $5 \mathrm{M} \mathrm{NaOH}$ was mixed with $3 \mathrm{~g}$ of dry WSW and heated in the water bath at $90^{\circ} \mathrm{C}$ for 1 h. Samples with water only were used as negative control. The mixture was filtered with Whatman No. 1 filter paper and $\mathrm{pH}$ adjusted to neutral. Liquid sample was used for a reducing sugar assay as described by Miller [23], after adjustment to $\mathrm{pH} 5$ using $1 \mathrm{M} \mathrm{HCl}$. The solid residue was autoclaved, and dried in an incubator for 5-7 days.

\section{G. Enzyme Hydrolysis}

Enzyme hydrolysis was carried out on the AHP pretreated WSW samples according to Rathore [21] with some modifications. Acetate buffer $(0.05 \mathrm{M})$ was used to make an enzyme dilution of 2:10. Three sets of flasks were autoclaved and prepared in duplicates for the enzyme hydrolysis, along with controls, as shown in Table I. 
TABLE I: STEPS IN ENZYME HYDROLYSIS OF WINERY SOLID WASTE

\begin{tabular}{|c|c|c|c|c|}
\hline \multirow{2}{*}{$\begin{array}{c}\text { AHP } \\
\text { pretreated } \\
\text { WSW } \\
\text { samples } \\
\end{array}$} & \multirow{2}{*}{$\begin{array}{c}\text { Biomass } \\
\text { (g) }\end{array}$} & \multicolumn{2}{|c|}{ Enzyme solution } & \multirow{2}{*}{$\begin{array}{c}\text { Buffer } \\
(\mathrm{mL})\end{array}$} \\
\hline & & Day 1 & Day 4 & \\
\hline 1 & 0.1 & $\begin{array}{c}2 \mathrm{~mL} \\
\text { ligninase }\end{array}$ & $\begin{array}{r}2 \mathrm{~mL} \\
\text { cellulase }\end{array}$ & 8 \\
\hline 2 & 0.2 & $\begin{array}{c}2 \mathrm{~mL} \\
\text { ligninase }\end{array}$ & $\begin{array}{r}2 \mathrm{~mL} \\
\text { cellulase }\end{array}$ & 8 \\
\hline 3 & 0.4 & $\begin{array}{c}2 \mathrm{~mL} \\
\text { ligninase }\end{array}$ & $\begin{array}{c}2 \mathrm{~mL} \\
\text { cellulase }\end{array}$ & 8 \\
\hline & & & & \multirow[b]{2}{*}{8} \\
\hline Control 1 & 0.1 & $\begin{array}{c}1 \mathrm{~mL} \\
\text { ligninase }+1 \\
\text { mL cellulase }\end{array}$ & $\begin{array}{r}\text { No } \\
\text { enzyme }\end{array}$ & \\
\hline Control 2 & 0.1 & $\begin{array}{c}2 \mathrm{~mL} \\
\text { ligninase }\end{array}$ & $\begin{array}{c}\text { No } \\
\text { enzyme }\end{array}$ & 8 \\
\hline Control 3 & 0.1 & $\begin{array}{c}2 \mathrm{~mL} \\
\text { cellulase }\end{array}$ & $\begin{array}{r}\text { No } \\
\text { enzyme }\end{array}$ & 8 \\
\hline $\begin{array}{l}\text { Non-AHP } \\
\text { pretreated }\end{array}$ & 0.1 & $\begin{array}{c}2 \mathrm{~mL} \\
\text { ligninase }\end{array}$ & $\begin{array}{r}2 \mathrm{~mL} \\
\text { cellulase. }\end{array}$ & 8 \\
\hline
\end{tabular}

Ligninase was added first to the sample and incubated at $35^{\circ}$ $\mathrm{C}$ for $72 \mathrm{~h}$. Lignin is the structure to be broken down before hemicellulose and cellulose hydrolysis. Samples were put in a water-bath at $90^{\circ} \mathrm{C}$ for $20 \mathrm{~min}$, in order to deactivate active enzymes. Sugar reducing assay was done on samples before cellulase was added and further incubated using rotary incubator $(60 \mathrm{rpm})$ at $50^{\circ} \mathrm{C}$. After 4 days, all sample reactions were terminated by repeating the deactivation procedure of active enzymes, and the reducing sugars measured. Controls were made to determine the effect of each enzyme as well as that of the AHP pretreatment on hydrolysis. The concentration of reducing sugar ( $\mathrm{x}$ ) in the samples was determined from absorbance values (y) using the glucose standard curve-See Eq. (4):

$$
\begin{aligned}
& y=0.1952 x+0.0053 ; x=\frac{y}{0.1952}-0.0053 \\
& y=\frac{\text { Sample A+Sample B }}{2}
\end{aligned}
$$

\section{RESULTS}

\section{A. Characterization of Winery Solid Waste}

The components of winery solid waste (WSW) used in this study were $95.92 \%$ and $83.86 \%$ of total solids and volatile solids, respectively. The main constituents were sodium $(1191.9 \mathrm{mg} / \mathrm{kg})$, total carbon $(50.40 \%)$, iron $(28.05 \mathrm{mg} / \mathrm{kg})$, ash $(15.95 \%)$ and protein $(11 \%)$ as shown in Table II.
TABLE II: COMPOSITION OF WINERY SOLID WASTE

\begin{tabular}{|c|c|c|}
\hline Characteristics & Unit & Dried winery waste \\
\hline Moisture content & $\%$ & 1.15 \\
\hline Total solids & $\%$ & 95.92 \\
\hline Volatile solids & $\%$ & 83.86 \\
\hline Protein & $\%$ & 11 \\
\hline Total nitrogen & $\%$ & 1.76 \\
\hline Total carbon & $\%$ & 50.40 \\
\hline Ash & $\%$ & 15.95 \\
\hline Calcium & $\%$ & 0.06 \\
\hline Phosphorus & $\%$ & 0.16 \\
\hline Potassium & $\mathrm{mg} / \mathrm{kg}$ & 1.77 \\
\hline Iron & $\mathrm{mg} / \mathrm{kg}$ & 28.05 \\
\hline Sodium & $\mathrm{mg} / \mathrm{kg}$ & 0.92 \\
\hline Cyanide & & \\
\hline
\end{tabular}

\section{B. Cellulose Degrading Bacteria}

Cellulose degrading bacteria (CDB) successfully isolated from ZD were identified mainly as actinomycetes and heterotrophs (Fig. 2). In a bid to increase the yield of cellulase enzymes, the effect of mechanical agitation on their production from isolated CDB was assessed. The results showed a significant difference in absorbance at $575 \mathrm{~nm}$ between the agitated and non-agitated samples. The non-agitated samples had higher reducing sugars indicating a higher quantity and activity of the $\mathrm{CDB}$ than in agitated cultures, which were subsequently used for further enzyme assay (Table III).

TABLE III: ABSORBANCE VALUES (575 nm) OF CDB CULTURES DURING ENZYME PRODUCTION

\begin{tabular}{|c|c|c|c|}
\hline Treatment & Samples & $\mathbf{A}_{575}$ & SD \\
\hline \multirow{2}{*}{$\begin{array}{c}\text { Agitated CDB } \\
\text { culture }\end{array}$} & A1 & 0.436 & 0.01 \\
\cline { 2 - 3 } & A2 & 0.455 & \\
\cline { 2 - 3 } & A3 & 0.421 & \\
\hline \multirow{2}{*}{$\begin{array}{c}\text { Non-agitated } \\
\text { CDB } \\
\text { Culture }\end{array}$} & B1 & $0.627^{*}$ & 0.00 \\
\cline { 2 - 3 } & B2 & - & \\
\cline { 2 - 3 } & B3 & 0.623 & \\
\hline
\end{tabular}

* CDB supernatant with the highest absorbance was used for enzyme (cellulase) assay; -, discarded.

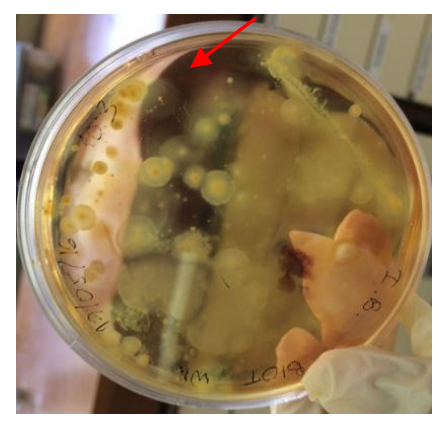

Fig. 2. CDB screening using Gram's iodine. Arrow indicates clear zone 
around the colonies after applying dye

\section{Production and Activity of Cellulase and Ligninase}

The introduction of Phanerochaete chrysosporium activated a steady increase in enzyme (ligninase) production. The activity of cellulase produced during $\mathrm{SmF}$ of $\mathrm{CDB}$ is also shown in Table IV.

TABLE IV: CELLULASE AND LIGNINASE ACTIVITIES OF THE ISOLATED CDB AND $P$. chrysosporium

\begin{tabular}{|c|c|c|c|c|}
\hline \multicolumn{3}{|c|}{ Cellulase activity $\left(\mathrm{A}_{575}\right)$} & $\begin{array}{c}\text { Ligninase } \\
\text { activity }\left(\mathrm{A}_{310}\right)\end{array}$ \\
\hline $\begin{array}{c}\text { Enzyme } \\
\text { dil. }\end{array}$ & $\begin{array}{c}\text { Absorbanc } \\
\text { e }\end{array}$ & $\begin{array}{c}\text { Glucose } \\
(\mathbf{m g} / \mathbf{m l})\end{array}$ & $\begin{array}{c}\text { Activity } \\
\text { (U/L) }\end{array}$ \\
\hline 0.1 & 0.043 & 0.21 & 21.48 \\
\hline 0.2 & 0.055 & 0.27 & 13.58 \\
\hline 0.4 & 0.066 & 0.32 & 10.70 \\
\hline 0.6 & 0.078 & 0.38 & & 3.58 \\
\hline 0.8 & 0.092 & 0.45 & & 2.86 \\
\hline 1.0 & 0.104 & 0.51 & & 2.08 \\
\hline
\end{tabular}

\section{Effects of Pretreatment}

WSW pretreated with alkaline hydrogen peroxide (AHP), yielded high amount of reducing sugar $(1.900 \mathrm{mg} / \mathrm{mL}$ reducing sugars on average) which was indicated by an increased absorbance values of $2.121 \pm 0.22$ (Mean: 0.1900 ) as shown in Table V.

TABLE V: ABSORBANCE VALUES OF RELEASED REDUCING SUGARS

\begin{tabular}{|l|l|}
\hline Pretreated samples & Absorbance (575 nm) \\
\hline Blank & 0.00 \\
\hline 1 & $1.851 \pm 0.05$ \\
\hline 2 & $1.730 \pm 0.171$ \\
\hline 3 & $2.121 \pm 0.22$ \\
\hline Control (Water + AHP) & 0.371 \\
\hline Mean & 0.1900 \\
\hline Standard deviation $(\sigma)$ & 0.1699 \\
\hline
\end{tabular}

\section{E. Enzyme Cocktail Hydrolysis}

The highest concentration $(0.66 \mathrm{mg} / \mathrm{mL})$ of reducing sugar was observed on day 4 when the cocktail of cellulase and ligninase enzymes (Table I) were used for hydrolysis, as opposed to the individual enzymes with lower concentrations (Fig. 4). There was a higher concentration of reducing sugar on day 7 for all samples except with the non-pretreated WSW biomass. The concentration of reducing sugar determined by means of the glucose standard curve linear equation is shown in Table VI.

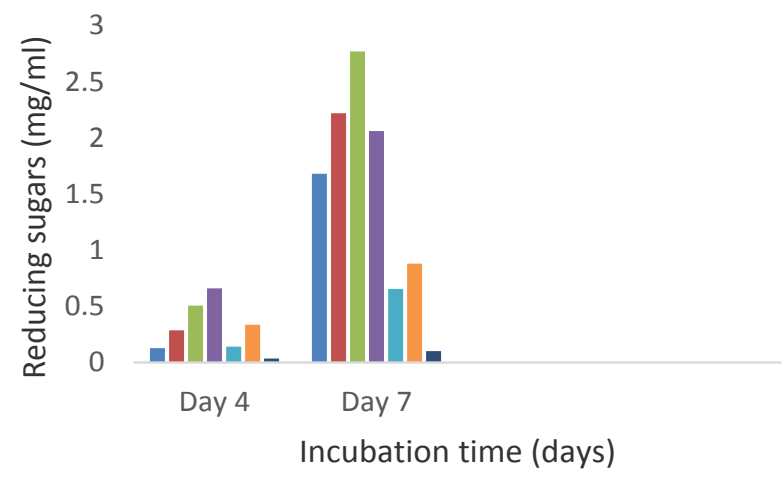

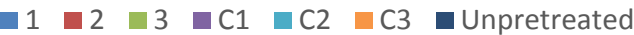

Fig.4. Reducing sugars yield over time during enzyme hydrolysis. Calculation of reducing sugars from absorbance values based on

Glucose standard curve equation $\mathrm{y}=0.1952 \mathrm{x}+0.0053 \mathrm{e} . \mathrm{g}$. $\mathrm{x}=0.130 / 0.1952-0.0053=0.660 \mathrm{mg} / \mathrm{ml}$

TABLE VI: VALUES OF REDUCING SUGARS AFTER DAY 4 AND 7 PRETREATMENTS WITH ENZYMES

\begin{tabular}{|c|c|c|}
\hline $\begin{array}{l}\text { AHP pretreated } \\
\text { WW samples }\end{array}$ & $\begin{array}{c}\text { Ligninase activity } \\
\text { (day 4) }\end{array}$ & Cellulase activity (day 7) \\
\hline & $\begin{array}{l}\text { Reducing } \\
\text { sugar } \\
(\mathrm{mg} / \mathrm{ml})\end{array}$ & $\begin{array}{l}\text { Reducing sugar } \\
(\mathrm{mg} / \mathrm{ml})\end{array}$ \\
\hline 1 & 0.128 & 1.68 \\
\hline 2 & 0.287 & 2.22 \\
\hline 3 & 0.506 & 2.77 \\
\hline Control 1 & 0.660 & 2.06 \\
\hline Control 2 & 0.143 & 0.656 \\
\hline Control 3 & 0.337 & 0.880 \\
\hline Non- pretreated & 0.036 & 0.102 \\
\hline
\end{tabular}

\section{DISCUSSION}

The impact of agitation on cellulose production was measured based on enzyme activity and it was found that the activity was higher in stationary cultures than in agitated cultures. This may be due to the release of some certain compounds produced intracellularly, that inhibit enzyme productivity or shearing effects [25]. Although activity varies with different species, the activity of cellulase produced by CDB was considerably higher in comparison to the average activity in commercial enzyme mixtures produced using microorganisms such as $T$. longibrachiatum and A. niger, as stated by Verardi et al. [15]. Alternatives for better outcomes would include raising the temperature to $40^{\circ} \mathrm{C}$ and $\mathrm{pH} 10$, as well as adding coconut cake, which was previously determined to act as a stimulus for cellulase production [22].

The ligninase activity was determined to be $21.48 \mathrm{U} / \mathrm{L}$. 
Consequential decrease in the activity of these enzymes would reduce the efficacy to degrade lignin. This could be due to influential factors such as the optimum $\mathrm{C}: \mathrm{N}$ ratio alteration and insufficient exposure to dissolved oxygen [26]. Bioreactor operational conditions play an important role in enzyme activity [20].

AHP had a higher impact on the pretreated samples, attributed to a higher delignification efficacy of the WSW as opposed to the untreated samples. This meant that AHP method was very effective in treating WSW. Several authors have reported similar findings [27], [28]. However, the use of AHP will be disadvantageous for AD plants operation using WSW due to the cost involved in purchasing pretreatment chemicals, as it is advisable to use environmentally benign methods. The best approach will be to combine the use of limited amounts with enzyme hydrolysis in a bid to save cost; albeit AHP has a better outcome as pretreatment method of lignocellulose biomass than other pre-treatment methods such as ammonia fiber expansion (AFEX) since hydrogen peroxide dissociates into oxygen and water, which pose minimal threat to the environment [16], [29].

The two enzymes produced in this study are ligninases and cellulases. Enzyme activity assay carried-out indicated sufficient production for the WSW pretreated, as Phanerochaete chrysosporium (white-rot fungus) is widely known for the production of ligninases such as lignin peroxidases for the degradation of lignin [30]. The use of detergents such as Tween 80 or Tween 20 can minimize ligninases deactivation due to mechanical inactivation caused by agitation without any adverse effects on the enzyme production rate or its ability to catalyze reactions [31], [32].

Cellulases include a mixture of various enzymes, but there are three main types: $\beta-1-4$-endoglucanases which target areas of low crystallinity; $\beta-1-4$-exoglucanases or cellobiohydrolases $(\mathrm{CBH})$ which remove cellobiose units and $\beta$-glucosidases (BG) that degrade the cellobiose into glucose [17].

Cellulase catalyzed hydrolysis showed successful conversion, with "Control 1" having the highest concentration of reducing sugars, meaning the enzyme cocktail containing both ligninases and cellulases worked better than when each enzyme was separately. This phenomenon is called synergism; however, the mechanism of action has still not well understood [33].

\section{CONCLUSION}

The pretreatment of WSW for the production of biogas was effective when carried out with AHP to solubilize lignin and decrystalinize cellulose in the lignocellulosic material, followed by saccharification in submerged fermentation, using an enzyme mixture of ligninases and cellulases. This is important in the biogas industry as the production process becomes much easier for the methanogenic microorganisms.

Of interest to the authors is measuring the percentage of lignin, hemicellulose and cellulose in the lignocellulosic material; running the same experiment using different identified CDBs found in the screening; purifying the enzymes produced, measuring reducing sugars over time as well as enzyme activity and finally using the produced sugars to generate biogas in an anaerobic digester. If this procedure and other forms of pretreatment are optimized to produce higher yields at a lower cost, it will facilitate the further development of a bio-refinery exclusively producing clean biogas for energy generation and bio-based products to boost the South African national bio-economy initiative.

\section{ACKNOWLEDGMENT}

This work is based on the research supported in part by the National Research Foundation of South Africa for the Thuthuka Unique Grant No. 99393. We are grateful to Mrs Mmabatho Mobo and $\mathrm{Mr}$ Micheal Tobin of the Department of Biotechnology for their technical assistant.

\section{REFERENCES}

[1] R. Gama, "A lignocellulolytic enzyme system for fruit waste degradation: Commercial enzyme mixture synergy and bioreactor design," $\mathrm{PhD}$. thesis, Dept. Biochem. and Microbio., Rhodes Univ., Grahams town SA, 2013.

[2] R. Devesa-Rey, X. Vecino, J. L. Varela-Alende, M. T. Barral, J. M. Cruz, and A. B. Moldes, "Valorization of winery waste vs. the costs of not recycling" Waste Management, vol. 31, pp. 2327-2335, Nov. 2011. https://doi.org/10.1016/j.wasman.2011.06.001

[3] Y. Zheng, J. Zhao, F. Xu, and Y. Li, "Pretreatment of lignocellulosic biomass for enhanced biogas production," Progress in Energy and Combustion Science, vol. 42, pp. 35-53, 2014. https://doi.org/10.1016/j.pecs.2014.01.001

[4] A. Mulidzi, "Environmental impact of winery effluent in the western and Northern Cape Provinces" Magister dissertation, Dept Plt Prod and Soil Sc., Univ. of Pretoria, SA, 2001.

[5] C. Dillon, "Waste Management in the South African Wine Industry" Diploma of Cape Wine Master dissertation, Cape Wine Academy, Cape Town, SA, 2011.

[6] Y. Mtimkulu, A. H. Meyer, A. R. Mulidzi, P. L. Shange, and F. Nchu, "Assessing and monitoring the effects of filter material amendments on the bio-physicochemical properties during composting of solid winery waste under open field and varying climatic conditions," Waste Management, vol. 59, pp. 59- 69, Jan. 2017. https://doi.org/10.1016/j.wasman.2016.10.042

[7] E. Dinuccio, P. Balsari, F. Gioelli, and S. Menardo, 2010. "Evaluation of the biogas productivity potential of some Italian agro-industrial biomasses" Bioresource Technology, vol. 101, pp. 3780-3783, 2010. https://doi.org/10.1016/j.biortech.2009.12.113

[8] R. Kumar, S. Singh, and O. V. Singh, "Bioconversion of Lignocellulosic Biomass: Biochemical and Molecular Perspectives," Journal of Industrial Microbiology and Biotechnology, vol. 35, pp. 377-391, 40 (28), May 2008.

[9] N. Mosier, C. Wyman, B. Dale, R. Elander, Y. Y. Lee, M. Holtzapple, and M. Ladisch, "Features of promising technologies for pretreatment of lignocellulose biomass," Bioresource Technology, vol. 96, pp. 673-686, April 2005. https://doi.org/10.1016/j.biortech.2004.06.025

[10] A. Hendriks, and G. Zeeman, "Pretreatments to enhance the digestibility of lignocellulosic biomass" Bioresource Technology, vol. 100, pp. 10-18, Jan. 2009 https://doi.org/10.1016/j.biortech.2008.05.027

[11] P. Harmsen, W. Huijgen, L. Lopez, and R. Bakker (September 2010). Literature Review of Physical and Chemical Pretreatment Processes for Lignocellulosic Biomass. [Online] Available: https://www.ecn.nl/docs/library/report/2010/e10013.pdf.

[12] J. Ariunbaatar, A. Panico, G. Esposito, F. Pirozzi, P. N. L. Lens, "Pretreatment methods to enhance anaerobic digestion of organic solid waste," Applied Energy, vo. 123, pp. 143-156, Feb. 2014. https://doi.org/10.1016/j.apenergy.2014.02.035

[13] V. Okudoh, C. Trois, T. and Workneh, "The Potential of Cassava Biomass as Feedstock for Sustainable Biogas Production in South Africa" Journal of Energy and Power Engineering, vol. 8, pp. 836-843, May 2014. 
[14] H. Hartmann, I. Angelidaki, and B. K. Ahring, "Increase of anaerobic degradation of particulate organic matter in full-scale biogas plants by mechanical maceration," Water Science and Technology, vol. 41, pp. 145-153, Feb. 2000. https://doi.org/10.2166/wst.2000.0066

[15] A. Verardi, I. De Bari, E. Ricca, and V. Calabro "Hydrolysis of lignocellulosic biomass: current status of processes and technologies and future perspectives," Bioethanol, 95-122, Feb. 2012.

[16] M. K. Gray, "Alkaline Hydrogen Peroxide pretreatment for its use in an on farm bioprocessing facility," Master thesis. Dept Biosys.Agricul. Eng. Univ. of Kentucky. 2013.

[17] S. Mussato, and J. Teixeira, "Lignocellulose as raw material in fermentation processes," in Current Research, Technology and Education Topics in Applied Microbiology and Microbial Biotechnology, A. Mendez-Vilas, Ed. Braga Portugal, FORMATEX, 2010, pp. 897-907.

[18] G. Maitan-Alfenas, E. Visser, and V. Guimarães, "Enzymatic hydrolysis of lignocellulosic biomass: converting food waste in valuable products," Current Opinion in Food Science, vol. 1, pp. 44-49, 2015. https://doi.org/10.1016/j.cofs.2014.10.001

[19] V. C Renge, S. V. Khedkar, and N. R. Nandurkar, "Enzyme synthesis by fermentation method: A Review," Scientific Reviews and Chemical Communications, vol. 2, pp. 585-590, Oct. 2012.

[20] S. K. O. Ntwampe, F. Chowdhury, M. Sheldon, and H. Volschenk, "Overview of parameters influencing biomass and bioreactor performance used for extracellular ligninase production from Phanerochaete chrysosporium" Brazilian Archives of Biology and Technology, vol. 53, pp. 1057-1066, Sept. 2010.

https://doi.org/10.1590/S1516-89132010000500008

[21] P. Rathore, "Cellulase production by liquid state fermentation of Bacillus species isolated from woody forest Soil. International Journal of Research Studies in Biosciences," vol. 2, pp. 8-13, June 2014.

[22] S. Sethi, A. Datta, B. L. Gupta, and S. Gupta, "Optimization of cellulase production from bacteria isolated from soil" ISRN Biotechnology, vol. 2013, pp. 1-7, Jan. 2013. https://doi.org/10.5402/2013/985685

[23] G. L. Miller, "Use of dinitrosalicylic acid reagent for the determination of reducing sugar," Analytical Chemistry, vol. 31, pp. 426-428, March 1959. https://doi.org/10.1021/ac60147a030

[24] E. Cabrera, M. Muñoz, R. Martín, I. Caro, C. Curbelo, and A. Díaz, "Alkaline and alkaline peroxide pretreatments at mild temperature to enhance enzymatic hydrolysis of rice hulls and straw" Bioresource Technology, vol. 167, pp. 1-7, Sept. 2014 https://doi.org/10.1016/j.biortech.2014.05.103

[25] D. Wase, W. McManamey, S. Raymahasay, and A. Vaid, "Comparisons between cellulase production by Aspergillus fumigatus in agitated vessels and in an air-lift fermentor" Biotechnology and Bioengineering, vol. 27, pp. 1166-1172, August 1985. https://doi.org/10.1002/bit.260270811

[26] X. Xiong, X. Wen, Y. Bai, and Y. Qian, "Effects of culture conditions on ligninolytic enzymes and protease production by Phanerochaete chrysosporium in air," Journal of Environmental Sciences, vol. 20, pp. 94-100, Jan. 2008. https://doi.org/10.1016/S1001-0742(08)60014-5

[27] S. Bolado-Rodriguez, C. Toquero, J. Martin-Juarez, R. Travaini, and P. A. Garcia-Encina, "Effect of thermal, acid, alkaline and alkaline-peroxide pretreatments on the biochemical methane potential and kinetics of the anaerobic digestion of wheat straw and sugarcane bagasse," Bioresource Technology, vol. 201, pp. 182-190, Nov. 2016. https://doi.org/10.1016/j.biortech.2015.11.047

[28] F. M. Pellera, S. Santori, R. Pomi, A. Polettini, and E. Gidarakos, "Effect of alkaline-pretreatment on anaerobic digestion of olive mill solid waste," Waste Management, vol. 58, pp. 160-168, Dec. 2016. https://doi.org/10.1016/j.wasman.2016.08.008

[29] K. Michalsk, and S. Ledakowicz, "Alkaline hydrogen peroxide pretreatment of energy crops for biogas production" Chemical Papers, vol. 68, pp. 913-922, July 2014.

[30] A. N. Glazer, and H. Nikaido, Microbial biotechnology: fundamentals of applied microbiology, $2^{\text {nd }}$ ed. New York: Cambridge University Press, 2007, p.444.

https://doi.org/10.1017/CBO9780511811227
[31] A. Jager, S. Croan, and T. K. Kirk, "Production of Ligninases and Degradation of Lignin in Agitated Submerged Cultures of Phanerochaete chrysosporium" Applied and Environmental Microbiology, vol. 50, pp. 1274-1278, Nov. 1985.

[32] R. Venkatadri, and R. Irvine, "Effect of agitation on ligninase activity and ligninase production by Phanerochaete chrysosporium" Applied and Environmental Microbiology, vol. 56, pp. 2684-2691, Sept. 1990.

[33] M. Kostylev, and D. Wilson, "Synergistic interactions in cellulose hydrolysis" Biofuels, vol. 3, pp. 61-70, Jan. 2012

https://doi.org/10.4155/bfs.11.150

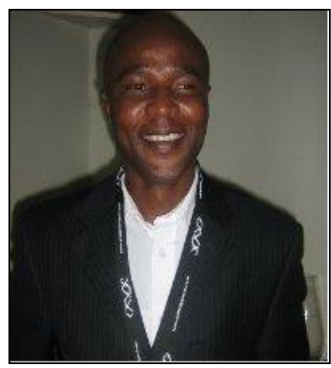

Dr. Vincent I. Okudoh completed his $\mathrm{MSc}$ and $\mathrm{PhD}$ in Industrial Microbiology at the University of KwaZulu-Natal (UKZN), South Africa in 2011. Up till 2013, he was a Postdoctoral Research Fellow and a member of the African Energy, Food and Water Research (AEFWR) group under Prof Cristina Trois where he initiated a study on the quantification of cassava biomass as potential feedstock for biogas production. He joined the Cape Peninsula University of Technology (CPUT) as a Lecturer in 2013 and currently a Senior Lecturer in the Department of Biotechnology. He has published articles in top-rated peer-reviewed journals and conference proceedings plus a book titled "Biogas Production in Africa: Benefit Potentials of Cassava Biomass" in 2015. He also contributed to a technical report "The State of Waste to Energy Research in South Africa: A Review" published by SA DoE Renewable Energy Centre for Research and Development (RECORD). Dr. Okudoh has received numerous awards and currently an NRF Thuthuka grant holder. He supervises a number of postgraduate students both Masters and $\mathrm{PhD}$. $\mathrm{He}$ is a member of the Golden Key International Honor Society for top academic achievers, American Society for Microbiology [ASM], and Society for Industrial Microbiologists \& Biotechnology (SIMB). He also belongs to South African Society for Microbiologists (SASM) and Bio-Resource Engineering Research Group (BioERG) at CPUT. 